\title{
KEBIJAKAN DISPORA KOTA PALEMBANG DALAM MEGEMBANGKAN MINAT MASYARAKAT UNTUK BEROLAHRAGA
}

\author{
Yogi Indrawan ${ }^{1}$, Endie Riyoko ${ }^{2}$ \\ Universitas PGRI Palembang ${ }^{1,2}$ \\ Yogiindrawan97@gmail.com ${ }^{1}$, endieriyoko@univpgri-palembang.ac.id ${ }^{2}$
}

\begin{abstract}
Abstrak
Hasil penelitian menunjukkan bahwa sejauh ini Dinas Pemuda dan Olahraga Kota Palembang telah berupaya semaksimal mungkin dalam membuat suatu kebijakan dan mewujudkan suatu pembinaan olahraga dengan baik dan menyeluruh kepada masyarakat, tujuannya untuk memudahkan setiap warga masyarakat yang ingin melakukan aktivitas olahraga dan mendapatkan pelayanan pembinaan olahraga secara menyeluruh terhadap semua fasilitas olahraga di kota Palembang. faktor pendukung dengan adanya pembinaan olahraga telah disediakan sarana dan prasarana olahraga yang memadai, faktor penghambatnya sendiri masih minimnya masyarakat yang mengerti pentingnya olahraga bagi kesehatan dan kebugaran tubuh, dan tanggapan masyarakat sendiri masyarakat senang karena merasa diperhatikan dengan adanya pembinaan olahraga dimasyarakat yang telah direncanakan oleh Dispora Kota Palembang.
\end{abstract}

Keywords: Kebijakan, Minat Masyarakat, Berolahraga

\section{THE POLICY OF DISPORA PALEMBANG IN THE COMMUNITY TO DEVELOP INTEREST TO SPORTS}

\begin{abstract}
.
The results showed that so far, the Palembang Young and Sports department has sought the greatest effort in making a policy and creating a well-rounded and thorough sports coaching to the public, its goal is to facilitate every citizen who wants to do sports activities and get a comprehensive sports coaching service to all sports facilities in the city of Palembang. Supporting factors with the existence of sports development has been provided adequate sports facilities and infrastructures, the decision factor itself still lack of society that understands the importance of sports for health and fitness of the body, and the public own response of society is pleased to feel cared for by the development of sport in the public that was planned by Dispora Palembang City.
\end{abstract}

Keywords: Policy,Minat Masyarakat, Sports

Correspondence author: Yogi Indrawan, Endie Riyoko, Universitas PGRI Palembang, Indonesia. E-Mail: yogiindrawan97@gmail.com 
Jurnal HalamanOlahraga Nusantara licensed under a Creative Commons Attribution-ShareAlike 4.0 International License.

\section{PENDAHULUAN}

Olahraga merupakan cara manusia untuk mempertahankan kesehatan jasmani. Mulai dari berlari, berenang, melompat, dan aktivitas olahraga lainnya. Berolahraga merupakan salah satu cara yang dapat dilakukan masyarakat urban/perkotaan untuk menjaga kesehatan dan kebugaran tubuh (Okilanda, 2018) serta mengembalikan kesegaran pikiran. Olahraga juga sbagai rangkaian gerak raga yang teratur dan terencana yang dilakukan secara sadar untuk dapat meningkatkan kemampuan fungsionalnya (Setiawan \& Triyanto, 2014).

Peranaan partisipasi masyarakat adalah ikut sertanya seluruh anggota masyarakat dalam memecahkan permsalahan-permasalahan masyarakat tersebut. Partisipasi masyarakat dibidang kesehatan berarti keikutsertaan seluruh anggota masyarakat dan memecahkan masalah kesehatan mereka sendiri dengan motivasi tertentu termasuk menjaga kesehatan (Wanto, 2018). Masyarakat sendiri yang akan memikirkan, merencanakan, melaksanakan, dan mengevaluasikan program-program kesehatan mereka. Institusi kesehatan hanya sekedar memotivasi dan membimbingnya (Riyoko \& Soegiyanto, 2014)

Pembangunan adalah konteks dimana kebijakan beroperasi. Sementara itu, kebijakan yang menunjuk pada kerangka kerja pembangunan, memberikan pedoman bagi pengimplementasian tujuan-tujuan pembangunan kedalam beragam program dan dan proyek (Riyoko \& Soegiyanto, 2014)

Sport DevelopmentIndex (SDI) diharapkan juga akan dapat menentukan tingkat kemajuan pembangunan olahraga suatudaerahdi Indonesia (Mutohir \& Maksum, 2007). Dalam konsep SDI terdapat beberapa indikator kemajuan pembangunan olahraga di indonesia, antaralain partisipasi masyarakat, Prasarana dan sarana olahraga (ruang terbuka), kebugaran jasmani dan sumber daya manusia. Keterlibatanpemerintahdalam hal ini yakni sebagai penanggung jawab pembangunan dalam rangka penyelenggaraan pembangunan kesehatan masyarakat dibidang olahraga sebagai salah satu unsur kesejahteraan umum yang 
merupakan tujuan nasional yang harus diwujudkan sesuai dengan cita-cita Bangsa Indonesia.

Indikator ruang terbuka merajuk pada luasnya fasilitas / lapangan yang tersedia disuatu daerah yang dapat digunakan masyarakat untuk melakukan kegiatan olahraga. Istilah sarana olahraga aadalah terjemahan dari facilities, yaitu sesuatu yang dapat digunakan dan dimanfaatkan dalam pelaksanaan kegiatan olahraga. Sedangkan prasarana secara umum berarti segala sesuatu yang merupakan penunjang terselenggaranya suatu proses (usaha atau pembangunan). Olahraga didefinisikan sebagai suatu yang mempermudah atau memperlancar tugas atau memiliki sifat yang relatif permanen salah satu sifat tersebut adalah tidak bisa dipindahkan.

Hal ini dilakukan untuk mensejahterakan masyarakat selain itu berguna mewujudkan sumber daya manusia yang berkualitas sehat jasmani dan rohani yang tertuang dalam Undang-Undang Nomor 3 Tahun (2005) tentang Sistem Keolahragaan Nasional yang menyatakan bahwa Keolahragaan nasional bertujuan untuk meningkatkan minat masyarakat terhadap olahraga, memelihara dan meningkatkan kesehatan dan kebugaran, prestasi, kualitas manusia, menanamkan nilai moral dan akhlak mulia, sportivitas, disiplin, mempererat dan membina persatuan dan kesatuan bangsa, memperkukuh ketahanan nasional, serta mengangkat harkat, martabat, dan kehormatan bangsa.

Berdasarkan hasil Observasi pendahuluan yang dilakukan pada tanggal 20 Oktober 2019 adapun kemajuannya terlihat dari segi pembangunan fasilitasfasilitas olahraga yang telah disediakan oleh Dispora kota Palembang dan digunakan oleh Masyarakat untuk berolahraga. Dibawah ini adalah fasilitas olahraga yang di sediakan oleh Dispora kota Palembang sebagai berikut : 
Tabel 1. Data Fasilitas Olahraga Dispora kota Palembang

\begin{tabular}{|c|c|c|}
\hline NO & Fasilitas Olahraga & Alamat \\
\hline 1. & Taman Ampera Skate Park & $\begin{array}{l}\text { Jl. Palembang Darussalam, } 9 \text { Ilir,Bukit Kecil, } \\
\text { Kota Palembang. }\end{array}$ \\
\hline 2. & Lapangan Sepakbola Hatta & $\begin{array}{l}\text { Kepandean Baru, Ilir Timur I, } \\
\text { Kota Palembang. }\end{array}$ \\
\hline 3. & Lapangan Sepakbola Kamboja & $\begin{array}{l}\text { Jl. Mayor Santoso, } 20 \text { Ilir D. III, Ilir Timur I, } \\
\text { Kota Palembang. }\end{array}$ \\
\hline 4. & Lapangan Badminton & $\begin{array}{l}\text { Kecamatan } 26 \text { Ilir, Bukit Kecil, } \\
\text { Kota Palembang. }\end{array}$ \\
\hline 5. & Lapangan Tenis Lapangan & $\begin{array}{l}\text { D. I, } 20 \text { Ilir D II, Ilir Timur. I, } \\
\text { Kota Palembang. }\end{array}$ \\
\hline
\end{tabular}

Sumber : Dispora Kota Palembang.

Seiring dengan fasilitas olahraga yang telah disediakan, tidak hanya pembinaan olahraga prestasi saja yang telah dibentuk, perlu adanya pembinaan olahraga dimasyarakatsupaya masyarakat tahu tentang pentingnya berolahraga bagi kesegaran tubuh dan memassalkan perkembangan olahraga yang ada di Indonesia.

Menanggapi perkembangan minat masyarakat dalam berolahraga dan kemajuan pembangunan fasilitas-fasilitas olahraga, sekarang inimenimbulkan permasalahanapakah pemerintah telahmengambil langkah-langkah yang baik, serta membuat suatu kebijakan dalam mempertahankan minat masyarakat untuk berolahraga serta pemeliharaan fasilitas-fasilitas olahraga yang diperuntukkan bagi masyarakat, kemudian tidak membedakan derajat, ras, suku, gender, budaya dan tidak ada pihak-pihak yang tidak berkepentingan yang memanfaatkan serta menguasai demi untuk kepentingan pribadi.

Kebijakan dan pembangunan adalah dua konsep yang terkait. Sebagai sebuah proses peningkatan kualitas hidup manusia, pembangunan adalah konteks dimana kebijakan beroperasi. Sementara itu, kebijakan yang menunjuk pada kerangka kerja pembangunan, memberikan pedoman bagi pengimplementasian tujuan-tujuan pembangunan kedalam beragam program dan proyek. 
Pemerintah kota Palembang melalui Dinas Pemuda dan Olahraga (DISPORA) sebagai penyusun dan pelaksana kebijakan daerah dibidang kepemudaan dan Olahraga tentu mempunyai kebijakan-kebijakan tertentu dalam mengembangkan minat masyarakat kota Palembang untuk berolahraga. Berdasarkan permasalahan diatas peneliti ingin mengetahui bagaimana langkahlangkah kebijakan Dispora kota Palembang dalam mengembangkan minat masyarakat untuk berolahraga.

Peraturan Daerah Pemerintah kota Palembang (2016) tentang Pembentukan dan Susunan Perangkat Daerah kota Palembang dan Peraturan Wali kota Palembang Nomor 61 tahun 2016 tentang kedudukan, susunan organisasi, tugas dan fungsi serta tata kerja dinas kepemudaan dan olahraga kota palembang yaitu tentang meningkatkan minat masyarakat terhadap olahraga. Pemerintah daerah mempunyai kewenangan untuk mengatur, membina, mengembangkan, melaksanakan, dan mengawasi penyelenggaraan keolahragaan di daerah sesuai dengan aturan Undang-Undang.

Keterlibatan pemerintah dalam hal ini yakni sebagai penanggung jawab pembangunan dalam rangka penyelenggaraan pembangunan kesehatan masyarakat dibidang olahraga sebagai salah satu unsur kesejahteraan umum yang merupakan tujuan nasional yang harus diwujudkan sesuai dengan cita-cita bangsa Indonesia. Pemerintah daerah dengan kewenangan yang dimililkinya merupakan faktor yang sangat berperan dalam pelaksanaan pambangunan (Juliartha, 2009). Kewenangan daerah Kabupaten/Kota juga merupakan bentuk dari kewenangan politik dan administratif yang mana bobot di Indonesia akan mencerminkan otonomi daerah tersebut.

Kebijakan (policy) seringkali penggunaannya dipetukarkan dengan istilahistilah lain seperti tujuan (goals), program, keputusan, undang-undang ketentuanketentuan, usulan-usulan dan rencana besar (Tahir, 2014). Bagi para pembuat kebijakan (policy makers) istilah-istilah tersebut tidaklah akan menimbulkan masalah apapun karena mereka menggunakan referensi yang sama.

Hayat (2018) menyatakan bahwa kebijakan publik adalah suatu keputusan yang dilakukan oleh pihak yang berwenang untuk kepentingan bersama. Setiap 
kebijakan publik tentunya mempunyai proses formulasi dan evaluasi yang mengikutinya. Eksekusinya berada pada level implementasi kebijakan. Semua proses kebijakan publik saling mempenaruhi satu sama lainnya, tidak bisa saling melemahkan, tapi sebaliknya harus saling menguatkan, sehingga kebijakan berjalan secara baik dan optimal.

Juliartha (2009) menyatakan bahwa implementasi kebijakan adalah tindakan-tindakan yang dilaksanakan oleh individu-individu dan kelompokkelompok pemerintah dan swasta yang diarahkan pada pencapaian tujuan dan sasaran yang telah ditetapkan.

Konsep SDI memiliki beberapa indikator kemajuan pembangunan olahraga di indonesia, antaralain partisipasi masyarakat, Prasarana dan sarana olahraga, ruang terbuka, kebugaran jasmani, dan sumber daya manusia sebagai berikut:

\section{1)Indikator Partisipasi}

Mutohir \& Maksum (2007) menyatakan bahwa secara umum lingkup partisipasi olahraga dapat mencangkup partisipasi langsung seperti melakukan olahraga dan tidak langsung seperti sebgai sponsor penyelenggaraan event olahraga. Secara khusus partisipasi olahraga merajuk pada keterlibatan langsung secara aktif sebagai pelaku olahraga. Olahraga tersebut dapat berbentuk olahraga formal seperti sepakbola, maupun tidak formal seperti olahraga tradisional. Demikian juga sifat olahraga yang dilakukannya dapat bersifat kreatif, kompetitif, dan olahraga untuk kesehatan atau kebugaran. Tempatnya dapat di lingkungan keluarga, masyarakat, atau sekolah yang sering disebut pendidikan jasmani. Angka partisipan olahraga diartikan sebagai tingkatan partisipasi masyrakat secara umum dalam olahraga yang dihitung berdasarkan perbandingan jumlah partisipan olahraga dengan jumlah populasi.

2) Indikator Ruang Terbuka

Mutohir \& Maksum (2007) menyatakan bahwa ruang terbuka merujuk pada suatu tempat yang di peruntukan bagi kegiatan olahraga oleh sejumlah orang (masyarakat) dalam bentuk bangunan dan/atau lahan. Bangunan dan/atau lahan tersebut dapat berupa lapangan olahraga yang standar atau tidak, yang tertutup (in-door) maupun terbuka (out-door), atau berupa lahan yang memang 
diperuntukkan untuk kegiatan berolahraga masyarakat. Angka ruang terbuka diukur berdasarkan rasio luas ruang terbuka dengan jumlah penduduk usia 7 tahun ke atas di suatu wilayah.

3) Indikator Kebugaran

Mutohir \& Maksum (2007) menyatakan bahwa kebugaran jasmani adalah kesanggupan tubuh untuk melakukan aktivitas tanpa mengalami kelelahan yang berarti. Orang yang bugar bararti ia tidak gampang lelah dan capek. Ia dapat mengerjakan kegiatn sehari-hari secara optimal, tidak malas atau bahkan berhenti sebelum waktunya. Jika mengacu pada definisi tersebut, tampaknya kondisi yang demikian belum dimiliki oleh sebagian besar masyarakat kita. Apalagi sehat secara paripurna sebagaimana definisi WHO. Ini mengingat, organisasi kesehatan dunia itu mendefinisikan sehat tidak hanya dari segi jasmani, melainkan juga rohani, dan sosial.

4) Indikator Sumber Daya Manusia

Mutohir \& Maksum (2007) menyatakan bahwa sumberdaya manusia (SDM) mengacu pada ketersediaan pelatih olahraga, guru Pendidikan Jasmani Olahraga, dan instruktur olahraga dalam suatu wilayah terentu. Angka SDM diukur berdasarkan rasio antara jumlah pelaltih, instruktur dan guru pendidikan jasmani dengan jumlah populasi yang berusia tujuh keatas di daerah yang bersangkutan.

Djaali (2017) menyatakan bahwa minat adalah rasa lebih suka dan rasa ketertarikan pada suatu hal atau aktivitas tanpa ada yang manyuruh. Minat pada dasarnya adalah penerimaan akan suatu hubungan antara diri sendiri dengan sesuatu di luar diri. Minat adalah kecenderungan untuk memperhatikan dan mengenang beberapa aktivitas (Djamarah 2002). Seseorang yang berminat terhadap suatu aktivitas akan memperhatikan aktivitas itu secara konsisten dengan rasa senang. Dengan kata lain, minat adalah suatu rasa lebih suka dan rasaa ketertarikan pada suatu hal atau aktivitas, tanpa ada yang menyuruh. Suatu rasa lebih suka dan rasa ketertarikan pada suatu hal atau aktivitas, tanpa ada yang menyuruh (Slameto, 2010). Minat pada dasarnya adalah penerimaan akan suatu hubungan antara diri sendiri dengan suatu diluar diri. Semakin kuat atau dekat 
hubungan tersebut, semakin besar minat.

\section{METODE}

Dalam penelitian ini, adapun lokasi yang menjadi tempat penelitian adalah di Kantor Dinas Pemuda dan Olahraga kota Palembang yang beralamat di Jl. Dr. Wahidin No.3, Talang Semut, Bukit Kecil, Kota Palembang. Penelitian ini akan di mulai pada akhir bulan Nopember tahun 2019 dan waktu penelitian ini dilakukan selama lebih kurang 1 minggu. Peneliti memilih lokasi penilitian ini karena kota Palembang adalah daerah yang mempunyai sarana olahraga yang cukup memadai di Provinsi Sumatera Selatan.

Berkaitan dengan kualitas suatu peneliti, objek penelitian yang sudah ditentukan yaitu Bapak AZ selaku Kepala Dispora kota Palembang dan sebagai unsur pembuat kebijakan, kemudian Pelatih di kota palembang, Guru pendidikan jasmani olahraga dan kesehatan di kota palembang, dan Masyarakat sekitar yang nantidapat menghasilkan gambaran yang reliabel atau dapat dipercaya mengenai Kebijakan Dispora kota Palembang dalam Mengembangkan Minat Masyarakat untuk Berolahraga.

Sugiyono (2017: 25) menyatakan bahwa Informan peneliti adalah orang yang memiliki kekuasaan, pengetahuan umum dan mau membukakan pintu kepada peneliti untuk bisa menjelajahi semua obyek yang diteliti. Sumber informasi dalam penelitian ini adalah Kepala Dispora Kota Palembang, Pelatih, Guru pendidikan jasmani olahraga dan kesehatan, dan Masyarakat sekitar.

Metode Penelitian kualitatif adalah metode penelitian yang berlandaskan pada filsafat postpositivisme, (sebagai lawannya adalah eksperimen) dimana peneliti adalah sebagai instrumen kunci, teknik pengumpulan data dilakukan secara triangulasi (gabungan), analisis data bersifat induktif/kualitatif, dan hasil penelitian kualitatif lebih menekan makna dari pada generalisasi. Tujuan utama penelitian kualitatif adalah untuk memahami dan mengeksplorasi fenomena utama pada objek yang diteliti, sehingga memperoleh pemahaman yang mendalam dan menemukan sesuatu yang unik (Sugiyono, 2017). Hal ini sesuai dengan tujuan penelitian untuk mengetahui bagaimana Kebijakan Dispora Kota Palembang 
dalam mengembangkan minat Masyarakat untuk berolahraga agar dapat memperoleh deskripsi yang mendalam tentang Kebijakan dalam Mengembangkan minat Masyarakat untuk Berolahraga.

Data yang dikumpulkan dalam penelitian kualitatif adalah berupa katakata, gambar dan bukan berupa angka-angka. Data yang didapat dalam penelitian ini didapat dari hasil observasi, wawancara dan dokumentasi, atau ketiganya di gabung triangulasi. Penelitian kualitatif, sampel sumber data pada tahap awal memasuki lapangan di pilih orang yang memiliki power dan otoritas pada situasi sosial atau objek yang diteliti, sehingga mampu membukakan pintu kemana saja peneliti akan mengumpulkan data (Sugiyono, 2017).

Sumber informan data pada penelitian ini adalah Bapak AZ selaku kepala Dinas Pemuda dan Olahraga kota Palembang. Teknik pengumpulan data merupakan langkah yang paling strategis dalam penelitian, karena tujuan utama dari penelitian adalah mendapatkan data. Tanpa mengetahui teknik pengumpulan data, maka peneliti tidak akan mendapatkan data yang memenuhi standar data yang ditetapkan. Penelitian kualitatif, pengumpulan data dilakukan pada natural setting (kondisi yang alamiah), sumber data primer, dan teknik pengumpulan data lebih banyak pada observasi berperan serta (participant observation), wawancara mendalam (in depth interview) dan dokumentasi (Sugiyono, 2017). Mengumpulkan informasi melalui pengamatan secara langsung, wawancara mendalam, dan dokumentasi.

\section{HASIL DAN PEMBAHASAN}

Kota Palembang adalah ibu kota provinsi Sumatra Selatan. Palembang adalah kota terbesar kedua di Sumatra setelah Medan. Kota Palembang memiliki luas wilayah $358,55 \mathrm{~km}^{2[4]}$ yang dihuni 1.573 .898 jiwa (2018) dengan kepadatan penduduk 4.800 per $\mathrm{km}^{2}$. Diprediksikan pada tahun 2030 mendatang kota ini akan dihuni 2,5 Juta orang. Pembangunan LRT (kereta api layang), dan rencana pembangunan sirkuit motor GP di kawasan Jakabaring dan sirkuit F1 di kawasan Tanjung Api-Api, merupakan proyek pengembangan Kota Palembang terkini. 
Sejarah Palembang yang pernah menjadi ibu kota kerajaan bahari Buddha terbesar di Asia Tenggara pada saat itu, Kerajaan Sriwijaya, yang mendominasi Nusantara dan Semenanjung Malaya pada abad ke-9 juga membuat kota ini dikenal dengan julukan "Bumi Sriwijaya". Berdasarkan prasasti Kedukan Bukit yang ditemukan di Bukit Siguntang sebelah barat Kota Palembang yang menyatakan pembentukan sebuah wanua yang ditafsirkan sebagai kota pada tanggal 16 Juni 688 Masehi menjadikan kota Palembang sebagai kota tertua di Indonesia. Di dunia Barat, kota Palembang juga dijuluki Venice of the East ("Venesia dari Timur"). Saat ini Wali Kota Palembang dijabat oleh Bapak H. Harnojoyo, S.Sos.

Secara geografis, Palembang terletak pada 2०59'27.99"LS $104^{\circ} 45^{\prime 24}$ 24"BT. Luas wilayah Kota Palembang adalah 358,55 $\mathrm{Km}^{2}$ dengan ketinggian rata-rata 8 meter dari permukaan laut. Letak Palembang cukup strategis karena dilalui oleh jalan Lintas Sumatra yang menghubungkan antar daerah di Pulau Sumatra. Palembang sendiri dapat dicapai melalui penerbangan dari berbagai kota di Indonesia seperti Jakarta, Bandung, Yogyakarta, Surabaya, Bandar Lampung, Bengkulu, Pangkal Pinang, Tanjung Pandan (via Pangkal Pinang), Jambi, Lubuk Linggau, Padang, Pekanbaru, Batam, Medan, dan Denpasar-Bali. Serta dari luar negeri yaitu Singapura, Kuala Lumpur, serta Jeddah (musim haji) Selain itu di Palembang juga terdapat sungai musi yang dilintasi Jembatan Ampera dan berfungsi sebagai sarana transportasi dan perdagangan antar wilayah.

Iklim Palembang merupakan iklim daerah tropis dengan angin lembap nisbi, kecepatan angin berkisar antara $2,3 \mathrm{~km} / \mathrm{jam}$ - 4,5 km/jam. Suhu kota berkisar antara 23,4 - 31,7 derajat celsius. Curah hujan per tahun berkisar antara $2.000 \mathrm{~mm}-3.000 \mathrm{~mm}$. Kelembaban udara berkisar antara $75-89 \%$ dengan ratarata penyinaran matahari $45 \%$. Topografi tanah relatif datar dan rendah. Hanya sebagian kecil wilayah kota yang tanahnya terletak pada tempat yang agak tinggi, yaitu pada bagian utara kota. Sebagian besar tanah adalah daerah berawa sehingga pada saat musim hujan daerah tersebut tergenang. Ketinggian rata-rata antara $0-$ 20 m dpl. 
Pada tahun 2002 suhu minimum kota terjadi pada bulan Oktober 22,70C, tertinggi 24,50C pada bulan Mei. Sedangkan suhu maksimum terendah 30,40C pada bulan Januari dan tertinggi pada bulan Sepetember 34,30C. Tanah dataran tidak tergenang air: $49 \%$, tanah tergenang musiman: $15 \%$, tanah tergenang terus menerus: $37 \%$ dan jumlah sungai yang masih berfungsi 60 buah (dari jumlah sebelumnya 108) sisanya berfungsi sebagai saluran pembuangan primer.

Tropis lembap nisbi, suhu antara 220-320 celcius, curah hujan 22$428 \mathrm{~mm} /$ tahun, pengaruh pasang surut antara 3-5 meter dan ketinggian tanah ratarata 12 meter dpl. Jenis tanah kota Palembang berlapis alluvial, liat dan berpasir, terletak pada lapisan yang paling muda, banyak mengandung minyak bumi, yang juga dikenal dengan lembah Palembang - Jambi. Tanah relatif datar dan rendah, tempat yang agak tinggi terletak dibagian utara kota. Sebagian kota Palembang digenangi air, terlebih lagi bila terjadi hujan terus menerus. Batas wilayah Kota Palembang adalah sebagai berikut:

1. Sebelah Utara berbatas dengan Kabupaten Banyuasin.

2. Sebelah Barat berbatasan dengan Kabupaten Banyuasin.

3. Sebelah Timur berbatasan dengan Kabupaten Banyuasin.

4. Sebelah Selatan berbatasan dengan Kabupaten Ogan Ilir dan Kabupaten Muara Enim.

Penduduk Palembang merupakan etnis Melayu dan menggunakan Bahasa Melayu yang telah disesuaikan dengan dialek setempat yang kini dikenal sebagai Bahasa Palembang. Namun para pendatang seringkali menggunakan bahasa daerahnya sebagai bahasa sehari-hari, seperti bahasa Komering, Rawas, Musi, Pasemah, dan Semendo. Pendatang dari luar Sumatra Selatan kadang-kadang juga menggunakan bahasa daerahnya sebagai bahasa sehari-hari dalam keluarga atau komunitas kedaerahan.

Namun untuk berkomunikasi dengan warga Palembang lain, penduduk umumnya menggunakan bahasa Palembang sebagai bahasa pengantar sehari-hari. Selain penduduk asli, di Palembang terdapat pula warga pendatang dan warga keturunan, seperti dari Jawa, Minangkabau, Madura, Bugis dan Banjar. Warga 
keturunan yang banyak tinggal di Palembang adalah Tionghoa, Arab dan India. Kota Palembang memiliki beberapa wilayah yang menjadi ciri khas dari suatu komunitas seperti Kampung Kapitan yang merupakan wilayah Komunitas Tionghoa serta Kampung Al Munawwar, Kampung Assegaf, Kampung Al Habsyi, Kuto Batu, 19 Ilir Kampung Jamalullail dan Kampung Alawiyyin Sungai Bayas 10 Ilir yang merupakan wilayah Komunitas Arab.

Berdasarkan Sensus Penduduk tahun 2015, persentase agama penduduk Kota Palembang adalah Islam 91.93\%, Buddha 3.46\%, Kristen Protestan 2.87\%, Katolik 1.65\%, Hindu 0.08\% dan Konghucu 0.01\%. Agama mayoritas di Palembang adalah Islam. Di dalam catatan sejarahnya, Palembang pernah menerapkan undang-undang tertulis berlandaskan Syariat Islam, yang bersumber dari kitab Simbur Cahaya. Selain itu terdapat pula penganut Katolik, Protestan, Hindu, Buddha dan Konghucu.

Pengakuan Bapak AZ selaku Kepala Dispora Kota Palembang tentang Kebijakan Dispora Kota Palembang dalam Mengembangkan Minat Masyarakat untuk Berolahraga telah dilakukan dari dahulu dan sudah mengacu pada empat aspek dalam mengembangkan minat masyarakat untuk berolahraga yaitu, aspek yang pertama disediakannya sarana dan prasarana atau ruang terbuka hujau guna digunakan masyarakat untuk berolahraga, kemudian aspek yang kedua sumber daya manusia yang berarti ketersediaan pelatih, instruktur olahraga, dan guru penjaorkes guna untuk mengembangkan minat dan bakat masyarakat dalam kegiatan berolahraga, kemudian aspek yang ketiga partisiparsi langsung dari masyakat sendiri maupun partisipasi tidak langsung seperti sebagai sponsor penyelenggaraan event olahraga, aspek yang keempat yaitu kebugaran yang dimaksud disini masyarakat sendiri harus bugar saat melakukan kegiatan olahraga maupun sudah melakukan aktivitas olahraga tanpa mengalami kelelahan yang berarti karena semua itu demi untuk mengolahragakan masyarakat supaya masyarakat tau pentingnya berolahraga untuk kebugaran maupun untuk meningkatkan prestasi di daerah.

Faktor pendukung Dispora Kota Palembang dalam Mengembangkan Minat Masyarakat untuk Berolahraga, tak lepas dari sarana dan prasarana yang sampai 
saat ini masih terawat dengan baik, ada juga fasilitas olahraga yang tidak terawat dengan baik, bahkan ada juga penambahan sarana dan prasarana baru. DalamhaliniDinasPemuda dan Olahraga Kota Palembang tentu saja memiliki rasa kebanggaan tersendiri melihat masyarakat yang masih berantusias mengikuti kegiatan olahraga. Itu semua bisa terwujud dari bentuk perhatian dari pemerintah dengan dibuatnya suatu kebijakan di olahraga, pelaksannan program kebijakan, pendanaan secara kontinyu dan berjenjang dengan didirikannya pembinaan olahragabaikprestasimaupun pembinaan di masyarakat, kemudian pelayanan dan kerjasama antar pemerintah Kota Palembang dengan masyarakat dan tidak terlepas dari partisipasi dan minat masyarakat untuk berolahraga.

Faktor penghambatnya adalah sebagian kecil masyarakat belum mengerti dan belum mempunyai kesadaran pentingnya olahraga untuk kebugaran tubuh, dalam hal ini pemerintah harus banyak mengadakan penyuluhan kepada masyarakat mengenai pentingnya olahraga bagi kebugaran dan kesegaran tubuh. Faktor penghambat lainya adalah masyarakat sendiri banyak menghabiskan waktu di pekerjaan kemudian mengalami kelelahan dan tidak sempat lagi melakukan kegiatan olahraga.

Kemudian sarana dan prasarana yang sekarang ini sudah mengalami sedikit kerusakan, namun itu jangan untuk dijadikan alasan atau masalah, yang terpenting adalah bagaimana mempertahankan minat serta partisipasi masyarakat dalam melakukan aktivitas berolahraga, paling tidak masyarakat mengerti tentang berolahraga yang dari tidak penting menjadi penting untuk kebugaran tubuh.

Tanggapan masyarakat menjadi pendukung terciptanya suatu Kebijakan yang telah dibuat dispora kota palembang dalam mengembangkan minat masyarakat untuk berolahraga, dimana masyarakat merasa senang sekali dan merasa diperhatikan kalau ada pembinaan olahraga di masyarakat dimana masyarakat ikut merasakan dan sangat berantusias dalam mengikuti program kegiatan olahraga yang dilaksanakan dispora kota palembang dalam mengembangkan minat masyarakat untuk berolahraga.

Kepala dinas pemuda dan olahraga kota palembang selalu konsen melihat kemajuan dan perkembangan minat masyarakat untuk berolahraga, namun seiring 
sudah dilaksanakannya suatu kebijakan tetapi pelaksanannya kurang berjalan dengan baik, kedepan kepada pelaku olahraga yang terkait agar selalu mengadakan even-even atau kompetisi di kelompok umur, tingkat kelurahan, tingkat kecamatan, tingkat tinggkat kota, tingkat provinsi, maupun tingkat nasional. Dan tidak hanya itu saja tentunya harus melakukan penyuluhan di bidang olahraga agar masyarakat tau tentang pentingnya olahraga bagi kebugaran tubuh dan tetap mau melakukan aktivitas olahraga serta membantu terselenggranya pelaksanaan program pembinaan olahraga yang ada di Kota Palembang.

\section{KESIMPULAN}

Hasil penelitian ini dapat disimpulkan bahwa sejauh ini Dinas Pemuda dan Olahraga Kota Palembang telah berupaya semaksimal mungkin dalam membuat suatu kebijakan dan mewujudkan suatu pembinaan olahraga dengan baik dan menyeluruh kepada masyarakat, tujuannya untuk memudahkan setiap warga masyarakat yang ingin melakukan aktivitas olahraga dan mendapatkan pelayanan pembinaan olahraga secara menyeluruh terhadap semua fasilitas olahraga di kota Palembang. Pemerintah daerah juga wajib mengalokasikan anggaran keolahragaan melalui Anggaran Pendapatan dan Belanja Negara (APBN) dan Anggaran Pendapatan dan Belanja Daerah (APBD) untuk mengalokasikan anggaran guna terlaksananya kegiatan olahraga dimasyarakat yang kecukupan dan berkelanjutan. Faktor pendukung dan penghambat Kebijakan Dispora Kota Palembang dalam mengembangkan minat masyarakat untuk berolahraga, telah disediakannya fasilitas-fasilitas olahraga untuk digunakan masyarakat melakukan aktivitas berolahraga yang cukup memadai, tetapi masyarakat sendiri masih belum menyadarari tentang pentingnya berolahraga bagi kebugaran tubuh. Kemudian tanggapan masyarakat sendiri tentang kebijakan Dispora Kota Palembang dalam mengembangkan minat masyarakat untuk berolahraga disambut baik oleh masyarakat, karena masyarakat merasa diperhatikan dengan adanya pembinaan olahraga dimasyarakat. 


\section{DAFTAR PUSTAKA}

Djaali, Djaali. 2017. Psikologi Pendidikan. Jakarta: Bumi Aksara.

Djamarah, Syaiful Bahri. 2002. Psikologi Belajar. Jakarta: Rineka Cipta.

Hayat, Hayat. 2018. "Kebijakan Publik Evaluasi, Reformasi Dan Formulasi." Malang: Intrans Publishing.

Juliartha, Edward. 2009. "Model Implementasi Kebijakan Publik.” Jakarta: Trio Rimba Persada.

Mutohir, Toho Cholik, and Ali Maksum. 2007. "Sport Development Index." Jakarta: PT Indeks.

Okilanda, Ardo. 2018. "Revitalisasi Masyarakat Urban/Perkotaan Melalui Olahraga Petanque." Halaman Olahraga Nusantara (Jurnal Ilmu Keolahragaan) 1(1).

Pemkot Palembang. 2016. Peraturan DaerahKota Palembang Tentang Pembn Perangkat Daerah Kota Palembang. Perda No.6 Tahun 2016.

Riyoko, Endie, and K. S. Soegiyanto. 2014. "Kebijakan Pemerintah Kabupaten Musi Banyuasin Dalam Mengembangkan Minat Masyarakat Untuk Berolahraga." Journal Of Physical Education and Sports 3(2).

Setiawan, Ipang, and Heri Triyanto. 2014. "Pengembagan Permainan Tradisonal Gobak Sodor Bola Dalam Pembelajaran Penjas Pada Siswa SD.” Media Ilmu Keolahragaan Indonesia 4(1).

Slameto, S. 2010. "Belajar Dan Faktor Yang Mempengaruhinya." Jakarta: Rineka Cipta.

Sugiyono, P. D. 2017. "Metode Penelitian Bisnis: Pendekatan Kuantitatif, Kualitatif, Kombinasi, Dan R\&D.” Penerbit CV. Alfabeta: Bandung.

Tahir, Arifin. 2014. Kebijakan Publik Dan Transparansi Penyelenggaraan Pemerintahan Daerah. Penerbit Alfabeta.

Undang-Undang, R. I. 2005. "No 3 Tahun 2005 Tentang Sistem Keolahragaan Nasional." Kementrian. Negara Pemuda Dan Olahraga Republik Indonesia. 
Kebijakan Dispora Kota Palembang Dalam Mengembangkan Minat Masyarakat Berolahraga

Wanto, Sugar. 2018. "Motivasi Anggota Pusat Kebugaran Dalam Mengikuti Latihan Fitness Pada Kota Sekayu." Halaman Olahraga Nusantara (Jurnal Ilmu Keolahragaan) 1(1). 